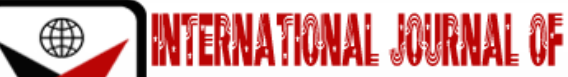

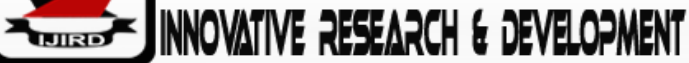

ISSN 2278-0211 (Online)

\section{Knowledge on Fire Disaster Preparedness among Heads of Schools, Teachers and Students in Secondary Schools in Kilimanjaro Region, Tanzania}

Emmanuel Jeremiah Kileo
Ph.D. Candidate, Department of Educational Management, Planning, Financing and Lifelong
Learning (DMPFL), Mwenge Catholic University, Tanzania
Gadi Koda
Faculty, Department of Educational Management, Planning, Financing and Lifelong Learning
(DMPFL), Mwenge Catholic University, Tanzania
Ogoti E. Okendo
Faculty, Department of Educational Management, Planning, Financing and Lifelong Learning
(DMPFL), Mwenge Catholic University, Tanzania

\begin{abstract}
:
This study was conducted to determine the level of knowledge on fire disaster preparedness among heads of schools, teachers and students in secondary schools in Kilimanjaro region, Tanzania. This study was guided by the Protection Motivation Theory (1975). This study employed cross-sectional survey research design under quantitative research approach and used stratified sampling to obtain the study sample. Data were collected through questionnaires administered to heads of schools, teachers, and students. The data were analyzed quantitatively through descriptive and inferential statistics. Findings revealed that respondents were moderately knowledgeable on fire disaster preparedness. Furthermore, the study revealed significant statistical difference in perceived level of knowledge on fire disaster preparedness between teachers in public and private secondary schools; and between teachers and students in secondary schools. The study concluded that only a fair number of respondents could effectively and efficiently respond to fire disasters, if they occurred at school and recommended for inter alia, regular training on fire safety, and integration of fire disaster management topics particularly, on fire disaster preparedness in the secondary education syllabi.
\end{abstract}

Keywords: Fire disaster, preparedness, knowledge, fire safety

\section{Introduction}

Establishing comprehensive safe learning environments is critical in ensuring quality education in schools. Safety in schools, from the physical, emotional and social point of view, is a constant concern for society and education management in particular (Díaz-vicario \& Sallán, 2017). Schools face a number of manmade and natural hazards which expose students and staff to among other things, physical and psychological harm. While students need to perceive that their school is safe for learning, this cannot happen when safety issues distract them because students who do not feel supported and safe at school, both physically and psychologically, cannot learn to their fullest potential. Therefore, a school should be environmentally and socially free of any potential harm or danger (NASP, 2013).

Disaster knowledge is essential in preparing students for associated adversities and should be given as early as possible (Nanda Khoirunisa, 2016). Similarly, disaster knowledge is crucial for teachers because they are not only responsible for their safety but also that of students. Studies however, show that both teachers and students have inadequate knowledge on disasters which leaves them even more vulnerable to incur the consequences of disasters at school, fire being a significant danger. For instance, a study conducted in Turkey by Pinar (2017) discovered that students lacked sufficient knowledge on disaster preparedness. Similarly a study conducted by Tuladhar et al. (2015) in Nepal revealed that teachers still had no enough knowledge on disasters, including fire. Furthermore, in South Africa, the study findings by Mugamu, (2018) confirmed that teachers lacked disaster emergency preparedness knowledge which translated into lack of preparedness to fire risks. In Tanzania, a study conducted by Mfinanga (2016) on status of emergency and disaster preparedness in boarding secondary schools in Singida region discovered inadequacy of knowledge on disaster preparedness among heads of schools, teachers, students, and security guards. Similarly, Nestory (2017) study conducted in Ilala Municipal council discovered that secondary school teachers had inadequate knowledge 
on fire safety preparedness. These studies generally show that teachers and students had inadequate knowledge on disaster preparedness in the two regions.

That novelty of this present study however, was grounded on addressing the perceived level of knowledge on disaster preparedness among teachers and students based on aspects that were considered by the researcher to be overlooked in the previously reviewed studies and those aspects related to fire disaster preparedness that have been paid little attention to across the previous reviewed studies.

\section{Statement of the Problem}

Knowledge on fire disaster preparedness is a vital indicator of fire safety in secondary schools. It is worth noting that several efforts are made by the Tanzanian government, among other stakeholders to ensure knowledge on fire disaster preparedness is imparted to students and staff in order to enhance fire safety in secondary schools. Such efforts include the Ministry of Education and Vocational training currently, the Ministry of Education Science and Technology issuing the 2011 Education Circular Number 4 which specifies that education stakeholders like the heads of schools should ensure regular trainings on fire safety management are conducted in schools. Despite such efforts, studies conducted on school fire safety in Tanzania for instance, Nestory (2017) and Amuli (2020) attest on the prevalence of fire disasters associated with inadequacy of knowledge on the matter. Nonetheless, there is little empirical evidence on the level of knowledge on fire disaster preparedness among students and teachers in Kilimanjaro region. This study therefore, sought to determine the perceived level of knowledge of students and teachers on fire disaster preparedness as an indicator of fire safety in secondary schools particularly, in Kilimanjaro region.

\section{Theoretical Framework}

This study was guided by the Protection Motivation Theory (PMT) propounded by Rogers (1975). The theory describes how individuals are motivated to react in a protective way towards perceived threat. Originally developed for the health promotion and disease prevention sector, Rogers expected the use of Protection Motivation Theory (PMT) to diversify over time, which has proved true over decades as this theory has been employed to guide studies on fire disaster preparedness; for example, Ayonga, (2016) andOgochukwu, Oduduabasi, and Anake, (2019). The theory has two main components: (1) threat appraisal, and (2) copping appraisal which link environmental influences to a behavior through a series of cognitive processes (Rogers, 1983;Akpi, 2019). The threat appraisal process focuses on the source of the threat and factors that increase or decrease likelihood of maladaptive behaviors (severity, vulnerability and rewards). When implied in this study, severity explains the degreed of harm that heads of schools, teachers and students could experience by not having adequate knowledge on fire disaster preparedness and vulnerability being the probability of incurring the consequences of a fire disaster. In addition, rewards (intrinsic and extrinsic) reflect the positive aspects of starting or continuing to ensure that sufficient knowledge on fire disaster preparedness among students and staff. Therefore, threat appraisal refers to students and staff members' evaluation of the degree to which fire disasters have significant implications for their well-being.

The coping appraisal entails the response efficacy, self-efficacy, and the response costs. Response efficacy is the effectiveness of having adequate knowledge on fire disaster preparedness in reducing or preventing possible harm from such menace. Self-efficacy is the belief that a student or teacher can successfully enact fire disaster preparedness practices. Nonetheless, self-efficacy is closely influenced by inter alia, the perceived level of knowledge among students and staff on fire disaster preparedness practices like how to use of portable fire extinguisher to put off fire, knowledge on classes of fire, and knowledge on types of extinguishing agent appropriate for each class of fire. The response costs are the costs associated with for example, imparting knowledge on fire disaster preparedness through training. The coping appraisal process therefore, focuses on the adaptive responses and students and staff ability to cope with and avert the threat. While knowledge on fire disaster preparedness is an important aspect that is associated with the ability of heads of schools, teachers and students to cope with fire disasters, the Protection Motivation Theory was considered applicable for this study as it entails cognitive mediating processes among its components.

\section{Review of Related Literature}

A case study was carried out in Lao People Democratic Republic (PDR) by Kanyasan et al. (2018) in eight secondary schools that were divided into two groups, the first group of schools which had partnered with Save the Children International (project schools) and the second group of school which did not (non-project schools). Comparing between the two groups of schools, students in the project schools were significantly more knowledgeable than the nonproject schools about an appropriate response on the aspects, 'reporting to a teacher' (98.4\% versus $93.3 \%$ ), 'evacuating during a fire' (86.4\% versus 79.1\%) and gathering at the 'assembly point' (87.3\% versus 96.0\%). While disaster preparedness is part and parcel of disaster risk reduction, the present study sought expand on the matter by determining the perceived level of knowledge on fire disaster preparedness not only among students but also among teachers in secondary schools.

Regarding knowledge on how to administer first aid in secondary schools, a study was conducted by Alharbi et al. in 2016 to explore the extent of knowledge on CPR skills among school teachers in Riyadh, KSA, Saudi Arabia. The findings revealed teachers' inadequate knowledge about CPR, a situation which exposed students to more danger, if a fire disaster occurred. As a result, the study concluded that majority of school teachers did not have adequate knowledge about CPR and therefore, recommended among other things, mandatory implementation of CPR and basic life-supporting training and refreshing courses for all school teachers across KSA. This current study however, not only involved teachers but involved students who were assessed of their perceived level of knowledge on how to administer first aid with focus on 
casualties of a fire disaster. Similar findings were revealed in another study by Gaikwad (2019) who assessed knowledge and attitude of secondary school teachers regarding first aid management of selected emergencies in Ghataprabha, India. The selected emergencies were nose-bleeding (epistaxis), fever, vomiting, epilepsy, and accidents. The study revealed that only a few teachers $(16 \%)$ had good knowledge. Furthermore, age was associated with level of knowledge of teachers and experience was associated with the level of knowledge of teachers. It was also found that there was a positive correlation between knowledge and attitude of school teachers regarding first aid management in emergencies. This study however, inquired on perceived level of knowledge among students and teachers on how to administer first aid to casualties of a fire disaster, if such menace occurred at school.

In Nigeria, a study conducted by Ogbonna and Nwaogazie (2015)inter alia, to determine the level of fire safety awareness in workplaces in Port Harcourt; including the education sector, revealed that respondents had good knowledge of fire safety issues, except on types of portable fire extinguishers. The results showed that majority (61\%) of the respondents did not know the types of portable fire extinguishers which further implied that majority of workers did not know the appropriate type of fire extinguishers to use for different classes of fire. The study therefore, suggested that the state of poor knowledge could put life into jeopardy.

Regarding fire safety preparedness knowledge and awareness among secondary school teachers, using a cross sectional survey design Nestory's (2017) conducted in secondary schools in Ilala Municipal findings revealed that majority of teachers had inadequate knowledge on fire safety preparedness. This study addressed the aspects: knowledge of fire emergency number to call, awareness of class A fire causes, knowledge of the main cause of death in fire accidents, knowledge of the use portable fire extinguishers labeled ABC, knowledge on how to use portable fire extinguishers, and the knowledge on evacuation from a building and calling or dialing the fire emergency number when the fire alarm is raised. The current study however, sought to determine specifically determine inter alia, the perceived level of knowledge on teachers and students on other overlooked variables like how to raise a fire alarm, classes of fire A, B, C, D, E, and F, and the use of other fighting equipment like the fire blanket.

The reviewed empirical studies present findings related to knowledge on fire disaster preparedness in secondary schools. They unveil that, majority of school secondary school teachers and students had little knowledge on fire disaster preparedness. While these studies established the level of knowledge based on particular fire disaster aspects, the novelty of the current study was to determine the perceived level of knowledge on fire disaster preparedness among teachers and students based on related aspects that the researcher considered to be overlooked and those that had been paid little attention to across the previously reviewed studies. For instance, the present study inquired on among other thing, knowledge on fire signs, exit and directional signs, methods of extinguishing fire, how to use sand bucket to put of fire, knowledge on possible cases requiring first aid if a fire disaster occurs at school.

\section{Research Methodology}

This study employed quantitative research approach. More specifically, the study employed the cross-sectional survey research design where data were collected from heads of schools, teachers and students. This study obtained its sample through stratification. Schools were stratified into two where a stratum of 21 public secondary schools and a stratum 14 private secondary schools were obtained and surveyed. Furthermore, 4 teachers and 6 students were sampled from each of these schools. It's also worth noting that teachers' sample from each school was obtained through stratification based on gender ( 2 male teachers and 2 female teachers). Similarly, the students' sample from each school was obtained through stratification based on gender thus, obtaining 3 male students and 3 female students from each sampled school. Furthermore, 35 heads of schools were involved in this study based on virtue of their positions. This study employed questionnaire method of data collection. The validity of questionnaires was enhanced through consultation with supervisors in the field of Educational Planning and Administration who shared their views with the researcher on how to improve the research instruments. Again, the feedback from the respondents in the pilot study was critical for necessary modification of the tools subsequently, ensuring validity of the research instruments that were used in the larger study.

The reliability of questionnaires was established by using SPSS to compute the Cronbach's Alpha coefficient for each instrument. According to Leary (2018) a Cronbach's alpha which exceeds .70 is considered adequate reliability by most researchers. Therefore, a Cronbach's alpha of .70 was considered acceptable reliability coefficient. Generally, all questionnaires had a Cronbach's Alfa coefficient above .70 where the questionnaire for heads of schools, teachers and students had the Cronbach's Alfa coefficients $.85, .76$ and .75 respectively. These instruments were therefore, considered to have acceptable reliability.

\section{Results and Discussion}

Table 1 shows heads of schools', teachers' and students' responses on their perceived level of knowledge on fire disaster preparedness in secondary schools. 


\begin{tabular}{|c|c|c|c|c|c|c|c|c|c|c|c|c|}
\hline \multirow[t]{2}{*}{ Statement } & \multirow[t]{2}{*}{ Respondents } & \multicolumn{2}{|c|}{ NKaA } & \multicolumn{2}{|c|}{ SK } & \multicolumn{2}{|c|}{ MK } & \multicolumn{2}{|c|}{ VK } & \multicolumn{2}{|c|}{ EK } & \multirow[t]{2}{*}{ Mean } \\
\hline & & f & $\%$ & f & $\%$ & f & $\%$ & f & $\%$ & f & $\%$ & \\
\hline \multirow{3}{*}{$\begin{array}{l}\text { Classes of fire A, B, } \\
\text { C, D, E, F }\end{array}$} & HOSs & 5 & 14.3 & 5 & 14.3 & 8 & 22.9 & 6 & 17.1 & 11 & 31.4 & 3.37 \\
\hline & Teachers & 29 & 21.0 & 26 & 18.8 & 33 & 23.9 & 26 & 18.8 & 24 & 17.4 & 2.93 \\
\hline & Students & 28 & 13.5 & 72 & 34.6 & 59 & 28.4 & 21 & 10.1 & 28 & 13.5 & 2.75 \\
\hline \multirow{3}{*}{$\begin{array}{c}\text { Types of } \\
\text { extinguishing } \\
\text { agents } \\
\text { appropriate for } \\
\text { each class of fire }\end{array}$} & HOSs & & & & & 13 & 37.1 & 9 & 25.7 & 13 & 37.1 & 4.00 \\
\hline & Teachers & 13 & 9.4 & 32 & 23.2 & 47 & 34.1 & 9 & 6.5 & 37 & 26.8 & 3.18 \\
\hline & Students & 15 & 7.2 & 33 & 15.9 & 51 & 24.6 & 63 & 30.4 & 45 & 21.7 & 3.43 \\
\hline \multirow{3}{*}{$\begin{array}{c}\text { Methods of } \\
\text { extinguishing fire }\end{array}$} & HOSs & 2 & 5.7 & 11 & 31.4 & 8 & 22.9 & 6 & 17.1 & 8 & 22.9 & 3.20 \\
\hline & Teachers & 68 & 49.6 & 26 & 19.0 & 19 & 13.9 & 12 & 8.8 & 12 & 8.8 & 2.08 \\
\hline & Students & 65 & 31.3 & 40 & 19.2 & 74 & 35.6 & 12 & 5.8 & 17 & 8.2 & 2.40 \\
\hline \multirow{3}{*}{$\begin{array}{l}\text { How to use a fire } \\
\text { blanket to put off } \\
\text { fire }\end{array}$} & HOSs & & & 7 & 20.0 & 5 & 14.3 & 4 & 11.4 & 19 & 54.3 & 4.00 \\
\hline & Teachers & 5 & 3.6 & 35 & 25.4 & 38 & 27.5 & 26 & 18.8 & 34 & 24.6 & 3.36 \\
\hline & Students & 9 & 4.3 & 32 & 15.4 & 62 & 29.8 & 65 & 31.3 & 40 & 19.2 & 3.46 \\
\hline \multirow{3}{*}{$\begin{array}{l}\text { Possible cases } \\
\text { requiring first aid, } \\
\text { if a fire disaster } \\
\text { occurs }\end{array}$} & HOSs & & & 12 & 34.3 & 11 & 31.4 & 5 & 14.3 & 7 & 20.0 & 3.20 \\
\hline & Teachers & 19 & 13.8 & 41 & 29.7 & 27 & 19.6 & 22 & 15.9 & 29 & 21.0 & 3.01 \\
\hline & Students & 61 & 29.5 & 31 & 15.0 & 31 & 15.0 & 55 & 26.6 & 29 & 14.0 & 2.81 \\
\hline \multirow{3}{*}{$\begin{array}{l}\text { How to use a } \\
\text { portable fire } \\
\text { extinguisher } \\
\text { (PASS method) }\end{array}$} & HOSs & 11 & 31.4 & 7 & 20.0 & 8 & 22.9 & 5 & 14.3 & 4 & 11.4 & 2.54 \\
\hline & Teachers & 66 & 47.8 & 19 & 13.8 & 22 & 15.9 & 16 & 11.6 & 15 & 10.9 & 2.24 \\
\hline & Students & 73 & 35.6 & 50 & 24.4 & 29 & 14.1 & 23 & 11.2 & 30 & 14.6 & 2.45 \\
\hline \multirow{3}{*}{$\begin{array}{l}\text { How to use a } \\
\text { bucket of sand to } \\
\text { put off fire }\end{array}$} & HOSs & & & & & 6 & 17.1 & 5 & 14.3 & 24 & 68.6 & 4.51 \\
\hline & Teachers & & & 11 & 8.0 & 29 & 21.1 & 52 & 38.0 & 45 & 32.8 & 3.96 \\
\hline & Students & 12 & 5.8 & 19 & 9.1 & 31 & 14.9 & 30 & 14.4 & 116 & 55.8 & 4.05 \\
\hline \multirow{3}{*}{$\begin{array}{l}\text { How to raise a fire } \\
\text { alarm }\end{array}$} & HOSs & & & 9 & 25.7 & 10 & 28.6 & 6 & 17.1 & 10 & 28.6 & 3.49 \\
\hline & Teachers & 9 & 6.7 & 71 & 52.6 & 24 & 17.8 & 14 & 10.4 & 17 & 12.6 & 2.70 \\
\hline & Students & 22 & 10.6 & 52 & 25.0 & 40 & 19.2 & 54 & 26.0 & 40 & 19.2 & 3.18 \\
\hline \multirow{3}{*}{$\begin{array}{l}\text { How to evacuate a } \\
\text { building on fire }\end{array}$} & HOSs & 2 & 5.7 & 14 & 40.0 & 8 & 22.9 & 6 & 17.1 & 5 & 14.3 & 2.94 \\
\hline & Teachers & 22 & 15.9 & 80 & 58.0 & 14 & 10.1 & 9 & 6.5 & 13 & 9.4 & 2.36 \\
\hline & Students & 50 & 24.3 & 34 & 16.5 & 54 & 26.2 & 46 & 22.3 & 22 & 10.7 & 2.79 \\
\hline \multirow{3}{*}{$\begin{array}{l}\text { How to administer } \\
\text { first aid to } \\
\text { casualties of a fire } \\
\text { disaster }\end{array}$} & HOSs & 3 & 8.6 & 14 & 40.0 & 7 & 20.0 & 11 & 31.4 & & & 2.74 \\
\hline & Teachers & 46 & 33.3 & 34 & 24.6 & 16 & 11.6 & 24 & 17.4 & 18 & 13.0 & 2.52 \\
\hline & Students & 63 & 30.7 & 59 & 28.8 & 20 & 9.8 & 22 & 10.7 & 41 & 20.0 & 2.60 \\
\hline \multirow{3}{*}{$\begin{array}{l}\text { Fire signs, exit and } \\
\text { directional signs }\end{array}$} & HOSs & 1 & 2.9 & 10 & 28.6 & 16 & 45.7 & 2 & 5.7 & 6 & 17.1 & 3.06 \\
\hline & Teachers & 59 & 42.8 & 40 & 29.0 & 16 & 11.6 & 11 & 8.0 & 12 & 8.7 & 2.11 \\
\hline & Students & 105 & 50.5 & 41 & 19.7 & 33 & 15.9 & 16 & 7.7 & 13 & 6.3 & 2.00 \\
\hline
\end{tabular}

Table 1: Responses on Level of Knowledge on Fire Disaster Preparedness among Heads of

Schools, Teachers and Students

Source: Field Data (2021)

Note: $\quad \mathrm{NKaA}$ - Not Knowledgeable at All

SK - Slightly Knowledgeable

MK - Moderately Knowledgeable

VK - Very Knowledgeable

EK - Extremely Knowledgeable

Findings in Table 1 shows that with regard to level of knowledge on classes of fire (A, B, C, D, E and F), of all heads of schools ( $\mathrm{n}=35), 5(14.3 \%)$ opined to have no knowledge at all on the matter, $5(14.3 \%)$ suggested that they were slightly knowledgeable, 8 (22.9\%) perceived that they were moderately knowledgeable, $6(17.1 \%)$ perceived that they were very knowledgeable and 11 (31.4\%) perceived to be extremely knowledgeable. Out of all teachers (n = 138) who responded with a mean of 2.93, 29 (21.0\%) opined to have no knowledge at all on the matter, 26 (18.8\%) suggest that they were slightly knowledgeable, 33 (23.9\%) opined that they were moderately knowledgeable, 26 (18.8\%) opined that they were very knowledgeable and $24(17.4 \%)$ opined to be extremely knowledgeable. With a mean of 2.75 , out of all students ( $\mathrm{n}=208), 28(13.5 \%)$ indicated that they were not knowledgeable at all, $72(34.6 \%)$ as being slightly knowledgeable, 59 (28.4\%) thought to be moderately knowledgeable, 21 (10.1\%) as being very knowledgeable and 28 (13.5\%) as being extremely knowledgeable. These findings reveal that the respondents had moderate level of knowledge on classes of fire which implies that if a fire disaster occurs, they might not correctly decide on the appropriate extinguishing agent for a specific class of fire. Nonetheless, class A fires involve solid materials such as wood or paper. Class B fires involve flammable liquids such as petrol, diesel of oils. Class C fires involve gases such as butane and propane natural gas. Class $\mathrm{D}$ 
fires involve combustible metals like sodium, aluminium or potassium. Class E fire involve electrical apparatus and class $\mathrm{F}$ fires involve oil and fats such as cooking oil and frying fat.

With a mean of4.00, heads of schools' responses on types of extinguishing agents appropriate for each class of fire indicated that $13(37.1 \%)$ perceived to be moderately knowledgeable, $9(25.7 \%)$ as being very knowledgeable and 13 $(37.1 \%)$ as being extremely knowledgeable. With a mean of3.18, 13 (9.4\%) of teachers perceived to have no knowledge at all on the aspect, $32(23.2 \%)$ opined to be slightly knowledgeable, $47(34.1 \%)$ as being moderately knowledgeable, 9 $(6.5 \%)$ as being very knowledgeable, and 37 (26.8\%) as being extremely knowledgeable. Of all students who responded with a mean of $3.43,15(7.2 \%)$ opined to have no knowledge at all on the aspect, 33 (15.9\%) thought to be slightly knowledgeable, $51(24.6 \%)$ opined to be moderately knowledgeable, $63(30.4 \%)$ as being very knowledgeable, and 45 $(21.7 \%)$ as being extremely knowledgeable on the matter. The findings showed that the respondents had moderate level of knowledge on types of extinguishing agents appropriate for each class of fire. These findings concur with Ogbonna \& Nwaogazie (2015) study findings in Nigeria which revealed that respondents had good knowledge on fire safety issues, except on types of portable extinguishers. The results implied that majority of them did not know the types of fire extinguishers which further suggested that majority of the respondents did not know the appropriate type of fire extinguisher to use for different classes of fire.

Furthermore, pertaining to methods of extinguishing fire, with a mean of 3.20, 2 (5.7\%) of all heads of schools perceived to have no knowledge at all on the aspect, 11 (31.4\%) thought to be slightly knowledgeable, 8 (22.9\%) suggested that they were moderately knowledgeable, $6(17.1 \%)$ as being very knowledgeable, 8 (22.9\%) as being extremely knowledgeable. The findings indicated that the heads of schools had a moderate level of knowledgeable on stages of fire. Of all teachers who responded with a mean of 2.08, 68 (49.6\%) perceived to have no knowledge at all on the issue, 26 (19.0\%) opined to be slightly knowledgeable, 19 (13.9\%) as being moderately knowledgeable, 12 (8.8\%) as being very knowledgeable, and $12(8.8 \%)$ as being extremely knowledgeable. Students responded with a mean of 2.40 on the matter where out of them all, 65 (31.3\%) perceived to have no knowledge at all, 40 (19.2\%) thought to be slightly knowledgeable, 74 (35.6\%) indicated that they were moderately knowledgeable, 12 (5.8\%) as being very knowledgeable, and $17(8.2 \%)$ as being extremely knowledgeable. The findings indicate that the respondents had a moderate level of knowledge on methods of extinguishing fire (Cooling, Starving and Smothering). Having adequate understanding on methods on how to extinguish fire is significant in that students and teachers can correctly judge which method is appropriate for extinguishing fire in different fire incidents considering the resources available not to incur more consequences of the fire.

The heads of schools responded with a mean of 4.00 in the views about their level of knowledge on how to use a fire blanket to put off fire, 7 (20.0\%) perceived to be slightly knowledgeable, $5(14.3 \%)$ as being moderately knowledgeable, 4 $(11.4 \%)$ as being very knowledgeable, and $19(54.3 \%)$ as being extremely knowledgeable. With a mean of 3.36, 5 (3.6\%) teachers opined to have no knowledge at all on how to use a fire blanket to put off fire, $35(25.4 \%)$ indicated that they were slightly knowledgeable, $38(27.5 \%)$ as being moderately knowledgeable, $26(18.8 \%)$ as being very knowledgeable and $34(24.6 \%)$ as being extremely knowledgeable. On the same matter, students responded with a mean of 3.46 where 9 (4.3\%) opined to have no knowledge at all, 32 (15.4\%) indicated that they were slightly knowledgeable, 62 (29.8\%) as being moderately knowledgeable, 65 (31.3\%) as being very knowledgeable, and 40 (19.2\%) as being extremely knowledgeable. The findings therefore, revealed that respondents had a moderate level of knowledge on how to use a fire blanket to extinguish fire which is also an indication that only fair number respondents could effectively extinguish fire using a fire blanket. Such a situation in schools reduces the chances of extinguishing a fire that might occur in schools using different means.

With a mean of $3.20,12(34.3 \%)$ heads of schools perceived to have a slight knowledge regarding possible cases requiring first aid, if a fire disaster occurred, 11 (31.4\%) though they were moderately knowledgeable, 5 (14.3\%) suggested they were very knowledgeable and 7 (20.0\%) thought they were extremely knowledgeable on the matter. On the same aspect, teachers responded with mean of 3.01 where 19 (13.8\%) thought to have no knowledge at all, 41 (29.7\%) though they were slightly knowledgeable, 27 (19.6\%) though they were moderately knowledgeable, 22 (15.9\%) opined to be very knowledgeable and 29 (21.0\%) perceived to be extremely knowledgeable. Students responded on the same matter with a mean of 2.81 where 61 (29.5\%) thought to have no knowledge at all, 31 (15.0\%) though they were slightly knowledgeable, 31 (15.0\%) though they were moderately knowledgeable, 55 (26.6\%) opined to be very knowledgeable and 29 (14.0\%) perceived to be extremely knowledgeable. These findings unveiled that the respondents had moderate level of knowledge on possible cases requiring first aid, if a fire disaster occurred. Being knowledgeable about cases that require first aid is imperative in helping casualties of a fire disaster who experience for example, burns, smoke suffocation, injury, and psychological distress among. These findings relate to Nestory (2017) findings which discovered that only $45.6 \%$ of the respondents were aware that suffocation from smoke is the main cause of death during a fire outbreak.

Regarding how to use a portable fire extinguisher to put off fire by following the Press, Aim, Squeeze and Sweep (PASS) method, heads of schools responded with a mean of 2.54 where 11 (31.4\%) perceived to have no knowledge at all, $7(20.0 \%)$ perceived that they were slightly knowledgeable, 8 (22.9\%) suggested that they were moderately knowledgeable, $5(14.3 \%)$ as being very knowledgeable, and $4(11.4 \%)$ as being extremely knowledgeable. Teachers responded with a mean of 2.24 where 66 (47.8\%) indicated to have no knowledge at all, 19 (13.8\%) suggested that they were slightly knowledgeable, 22 (15.9\%) though to be moderately knowledgeable, 16 (11.6\%) opined to be very knowledgeable and $15(10.9 \%)$ as being extremely knowledgeable. The data suggest that teachers were slightly knowledge on how to use fire extinguishers. These findings coincide with Nestory (2017) which revealed that only $28 \%$ of the respondents who were teachers opined to be able to use fire extinguishers to put off fire. In addition, with a mean of $2.43,73(35.6 \%)$ of the students perceived to have no knowledge at all on matter, $50(24.4 \%)$ indicated that they were 
slightly knowledgeable, 29 (14.1\%) suggested that they were moderately knowledgeable, 23 (11.2\%) as being very knowledgeable, and 30 (14.6\%) as being extremely knowledgeable. These findings unveiled that the respondents were slightly knowledgeable on how to use a fire extinguisher by following the PASS method. Subsequently, the findings implied that only a few heads of schools, teachers and students could correctly use a portable fire extinguisher thus making the school community more vulnerable to incur the consequences of a fire disaster, should such menace occur.

Heads of schools' responses with a mean of 4.51 pertaining to how to use a bucket of sand to put off fire were reflected by $6(17.1 \%)$ of these respondents who perceived to be moderately knowledgeable on the matter, 5 (14.3\%) who perceived to be very knowledgeable and $24(68.6 \%)$ as being extremely knowledgeable. On the same aspect 11 (8.0\%) of teachers perceived that they were slightly knowledgeable, 29 (21.1\%) as being moderately knowledgeable, 52 (38.0\%) as being very knowledgeable, and $45(32.8 \%)$ as being extremely knowledgeable. Students responded with a mean of 4.05 where 12 (5.8\%) thought they had no knowledge at all on the use of sand buckets, 19 (9.1\%) opined to be slightly knowledgeable, 31 (14.9\%) as being moderately knowledgeable, 30 (14.4\%) as being very knowledgeable and 116 $(55.8 \%)$ as being extremely knowledgeable. The findings revealed that the respondents were very knowledgeable on how to use a bucket of sand to put off fire. the findings therefore, implied that should a fire disaster occur, heads of schools, teachers and students could effectively use sand buckets at school to extinguish fire.

With regards to how to raise a fire alarm, heads of schools responded with a mean of 3.49 where 9 (25.7\%) perceived to be slightly knowledgeable on the matter, 10 (28.6\%) perceived to be moderately knowledgeable, 6 (17.1\%) as being very knowledgeable, and $10(28.6 \%)$ as being extremely knowledgeable. Teachers responded with a mean of 2.70 on the matter where $9(6.7 \%)$ indicated to have no knowledge at all, $71(52.6 \%)$ perceived to be slightly knowledgeable, $24(17.8 \%)$ perceived to be moderately knowledgeable, 14 (10.4\%) perceived to be very knowledgeable, and 17 (12.6\%) as being extremely knowledgeable. Again, on the same aspect, students responded with a mean of 3.18 where 22 (10.6\%) opined to have no knowledge at all, 52 (25.0\%) indicated to have slight level of knowledge, 40 (19.2\%) though to be moderately knowledgeable, $54(26.0 \%)$ as being very knowledgeable and $40(19.2 \%)$ as being extremely knowledgeable on how to raise a fire alarm. The findings suggested that the respondents were moderately knowledgeable about how to raise a fire alarm. The findings implied that in such a situation if a fire occurs, it could spread quickly, cause more destruction to school premises, and harm to school community members.

Heads of schools' responses with a mean of 2.94 pertaining to how to evacuate a building on fire were reflected by $2(5.7 \%)$ of these respondents who perceived to have no knowledge at all on the matter, $14(40.0 \%)$ who opined that they were slightly knowledgeable, $8(22.9 \%)$ as being moderately knowledgeable, $6(17.1 \%)$ as being very knowledgeable, and $5(14.3 \%)$ as being extremely knowledgeable. On the same aspect, with a mean of $2.24,22(15.9 \%)$ of teachers perceived that they had no knowledge at all, 80 (58.0\%) perceived to be slightly knowledgeable, 14 (10.1\%) as being moderately knowledgeable, $9(6.5 \%)$ as being very knowledgeable, and $13(9.4 \%)$ as being extremely knowledgeable. Students responded with a mean of 2.79 where 50 (24.3\%) perceived that they had no knowledge at all on the matter, 34 (16.5\%) opined to be slightly knowledgeable, 54 (26.2\%) as being moderately knowledgeable, 46 (22.3\%) as being very knowledgeable, and $22(10.7 \%)$ as being extremely knowledgeable. These findings suggested that the respondents had a moderate level of knowledge on how to evacuate a building on fire. These findings contravene Kanyasan et al. (2018) study findings in the Lao People Democratic Republic (PDR) which revealed that students had adequate knowledge on how to evacuate a building on fire. The findings therefore, implied that should a fire disaster occur, heads of schools, teachers and students could not efficiently escape from a building on fire which increases their vulnerability to more harm associated with a fire disaster.

With a mean of $2.74,3(8.6 \%)$ of heads of schools perceived that they were not knowledgeable at all on how to administer first aid to casualties of a fire disaster, 14 (40.0\%) opined to be slightly knowledgeable, 7 (20\%) suggested that they were moderately knowledgeable, and 11 (31.4\%) indicated that they were very knowledgeable. On the same matter, with a mean of 2.52, $46(33.3 \%)$ of teachers perceived that they were not knowledgeable at all, 34 (24.6\%) perceived to be slightly knowledgeable, 16 (11.6\%) suggested that they were moderately knowledgeable, $24(17.4 \%)$ indicated that they were very knowledgeable, and $18(13.0 \%)$ as being extremely knowledgeable. These findings coincide with the study conducted by Gaikwad (2019) who revealed that most of the teachers (48\%) had poor knowledge, 36\% of teachers had average knowledge, and only $16 \%$ of teachers had a good knowledge regarding first aid management of selected emergencies. Similarly, Alharbi et al. (2016) findings revealed that teachers' had inadequate knowledge about CPR, a situation which exposed students to more danger, if a fire disaster occurred. Furthermore, with a mean of 2.60, 63 (30.7\%) of the students perceived to have no knowledge at all on how to administer first aid, 59 (28.8\%) opined to be slightly knowledgeable, 20 (9.8\%) perceived to be moderately knowledgeable, $22(10.7 \%)$ as being very knowledgeable, and 41 $(20 \%)$ as being extremely knowledgeable. These finding unveiled that the respondents had a moderate level of knowledge on how to administer first aid. These findings implied that only a fair number of heads of schools, teachers and students could administer first aid to casualties of a fire disaster, a situation that increases the risk of victims not receiving assistance they need to be relived from experiencing suffering induced by the menace.

With regards to fire signs e.g., exit and directional signs, heads of schools responded with a mean of 3.06 where 1 (2.9\%) perceived to have no knowledge at all on the matter, 10 (28.6\%) perceived to be slightly knowledgeable, 16 (45.7\%) perceived to be moderately knowledgeable, 2 (5.7\%) as being very knowledgeable, and 6 (17.1\%) as being extremely knowledgeable. On the same aspect, teachers responded with a mean of 2.11 where 59 (42.8\%) perceived to have no knowledge at all, 40 (29.0\%) perceived to be slightly knowledgeable, 16 (11.6\%) perceived to be moderately knowledgeable, 11 (8.0\%) perceived to be very knowledgeable, and 12 (8.7\%) perceived to be extremely knowledgeable. Again, on the same matter, students responded with a mean of 2.0 where $105(50.5 \%)$ perceived to have no knowledge at all on the matter, 41 (19.7\%) perceived to be slightly knowledgeable, 33 (15.9\%) perceived to be moderately 
knowledgeable, $16(7.7 \%)$ perceived to be very knowledgeable and $13(6.3 \%)$ perceived to be extremely knowledgeable. The findings suggested that the respondents were slightly knowledgeable about fire signs, exit and directional signs a situation that exposes them to greater risk of incurring the consequences of a fire disaster by not being able to understand for example, routes to follow when escaping a building on fire.

\section{Null Hypothesis Testing}

The following null hypotheses were tested in this study:

\subsection{Null Hypothesis 1}

There is no significant statistical difference between the teachers' mean scores on level of knowledge on fire disaster preparedness in public and private secondary schools in Kilimanjaro region.

\begin{tabular}{|c|c|c|c|c|c|c|c|c|c|c|}
\hline & \multicolumn{2}{|c|}{$\begin{array}{l}\text { Levene's Test for } \\
\text { Equality of } \\
\text { Variances }\end{array}$} & \multicolumn{7}{|c|}{ t-test for Equality of Means } \\
\hline & & \multirow[t]{2}{*}{$\mathbf{F}$} & \multirow[t]{2}{*}{ Sig. } & \multirow[t]{2}{*}{$\mathbf{t}$} & \multirow[t]{2}{*}{ Df } & \multirow[t]{2}{*}{$\begin{array}{c}\text { Sig. } \\
\text { (2-tailed) }\end{array}$} & \multirow[t]{2}{*}{$\begin{array}{c}\text { Mean } \\
\text { Difference }\end{array}$} & \multirow[t]{2}{*}{$\begin{array}{l}\text { Std. Error } \\
\text { Difference }\end{array}$} & \multicolumn{2}{|c|}{$\begin{array}{l}\text { 95\% Confidence } \\
\text { Interval of the } \\
\text { Difference }\end{array}$} \\
\hline & & & & & & & & & Lower & Upper \\
\hline \multirow[t]{2}{*}{ Mean } & 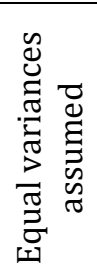 & $\begin{array}{l}\text { ठో } \\
\text { ம? }\end{array}$ & 岁 & $\stackrel{\substack{m \\
m}}{\stackrel{m}{1}}$ & $\underset{\sim}{\sim}$ & ชิ & $\begin{array}{l}\infty \\
0 \\
0 \\
\infty \\
? \\
?\end{array}$ & $\begin{array}{l}\text { वे } \\
\text { o } \\
\text { เn } \\
0\end{array}$ & 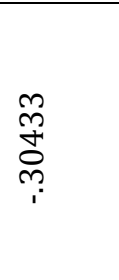 & $\begin{array}{l}\text { m } \\
8 \\
0 \\
0 \\
0\end{array}$ \\
\hline & 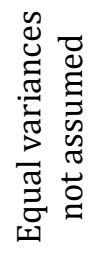 & & & $\begin{array}{l}\stackrel{L}{\circ} \\
\stackrel{\sim}{n}\end{array}$ & 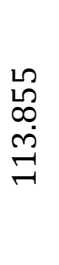 & ชै & $\begin{array}{l}\infty \\
0 \\
\stackrel{0}{0} \\
\infty \\
\rightarrow \\
i\end{array}$ & 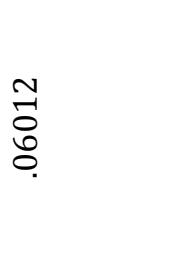 & $\begin{array}{l}\text { 尺ิ } \\
\text { นิ } \\
\text { r! }\end{array}$ & $\begin{array}{l}\hat{n} \\
\hat{\mathrm{L}} \\
\stackrel{0}{0}\end{array}$ \\
\hline
\end{tabular}

Table 2: Teachers' Independent Samples t Test

Source: Field Data 2021

Table 2 indicates that the Levene's Test for equality of variance when $p$ value for equal variances assumed is .454, $t$ is -3.138 , degrees of freedom (df) is 136 and $p$ value is .002 .

The decision rule suggests that, if the $p$ value is less than the alpha, then the null hypothesis is rejected and if the $p$ value is greater than the alpha, we fail to reject the null hypothesis. In this test, the $p$ value (2-tailed) was .002 thus, rejection of the null hypothesis. The findings therefore, implied that there was a significant statistical difference between teachers' perceived level of knowledge of on fire disaster preparedness in public $(\mathrm{M}=2.69, \mathrm{SD}=.34)$ and private $(\mathrm{M}=2.86$, $\mathrm{SD}=.35)$ secondary schools in Kilimanjaro region; $t(136)=-3.14, p=.002$.

The findings showed that private secondary school teachers had a greater mean compared to that of the public secondary school teachers. These findings therefore, suggested that teachers in private schools might have been receiving more training on fire safety compared to teachers in public schools. Apparently, this might have been due to more efforts made by private school managers and administrators to ensure that staff members in their schools are imparted with adequate knowledge on fire disaster management at school, where fire disaster preparedness is an important component of fire disaster management.

\subsection{Null Hypothesis 2}

There is no significant statistical difference between students' mean scores on the level of knowledge on fire disaster preparedness in public and private secondary schools. 


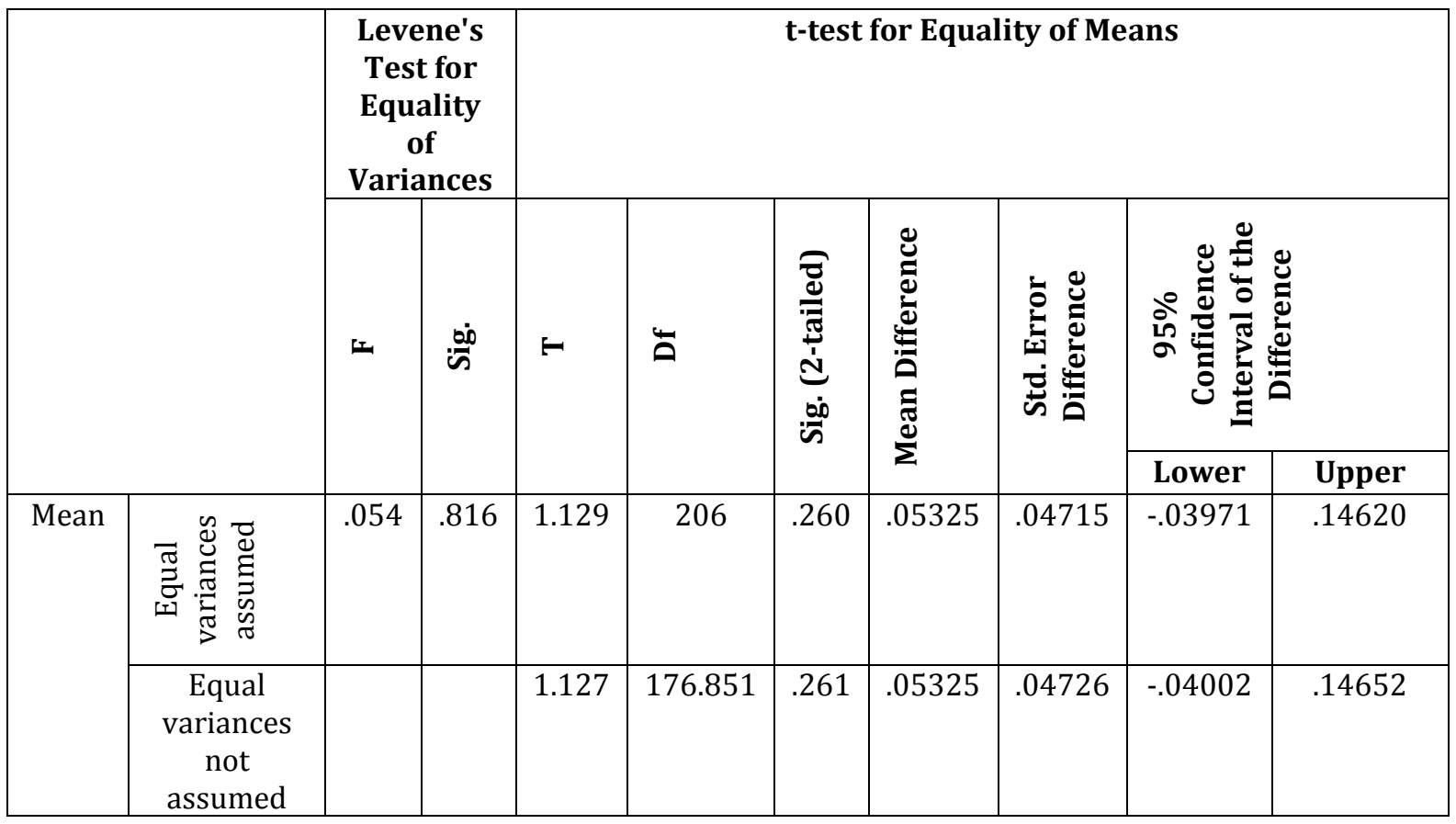

Table 3: Students' Independent Samples T Test

Source: Field Data (2021)

Table 3 indicates that the Levene's Test for equality of variance when $p$ value for equal variances assumed is .816, $t$ is 1.129 , degrees of freedom (Df) is 206 and $p$ value is .260 .

The decision rule suggests that, if the $p$ value is less than the alpha, then the null hypothesis is rejected and if the $p$ value is

greater than the alpha, we fail to reject the null hypothesis. In this test, the $p$ value (2-tailed) was .26 thus, we failed to reject the null hypothesis. The findings therefore, implied that there was no significant statistical difference between students' perceived level of knowledge on fire disaster preparedness in public $(\mathrm{M}=2.97, \mathrm{SD}=.33)$ and private $(\mathrm{M}=2.92, \mathrm{SD}=.34)$ secondary schools in Kilimanjaro region; $t(206)=1.13, p=.26$.

While the findings showed that there was no significant statistical difference between students' level of knowledge on fire disaster preparedness in public and private schools, this could be due to the fact that students, regardless of being in public or private secondary schools, use the same secondary education syllabi which incorporates aspects of fire safety. For instance, the ordinary level Chemistry syllabus integrates aspects related to fire disaster preparedness in Form one sub-topics like 'fire-fighting'. Similarly, the ordinary level Biology syllabus incorporates Form one sub-topics on first aid and first aid administration.

\subsection{Hypothesis 3}

There is no significant statistical difference between teachers' and students' mean scores on their perceived level of knowledge on fire disaster preparedness in secondary schools. 


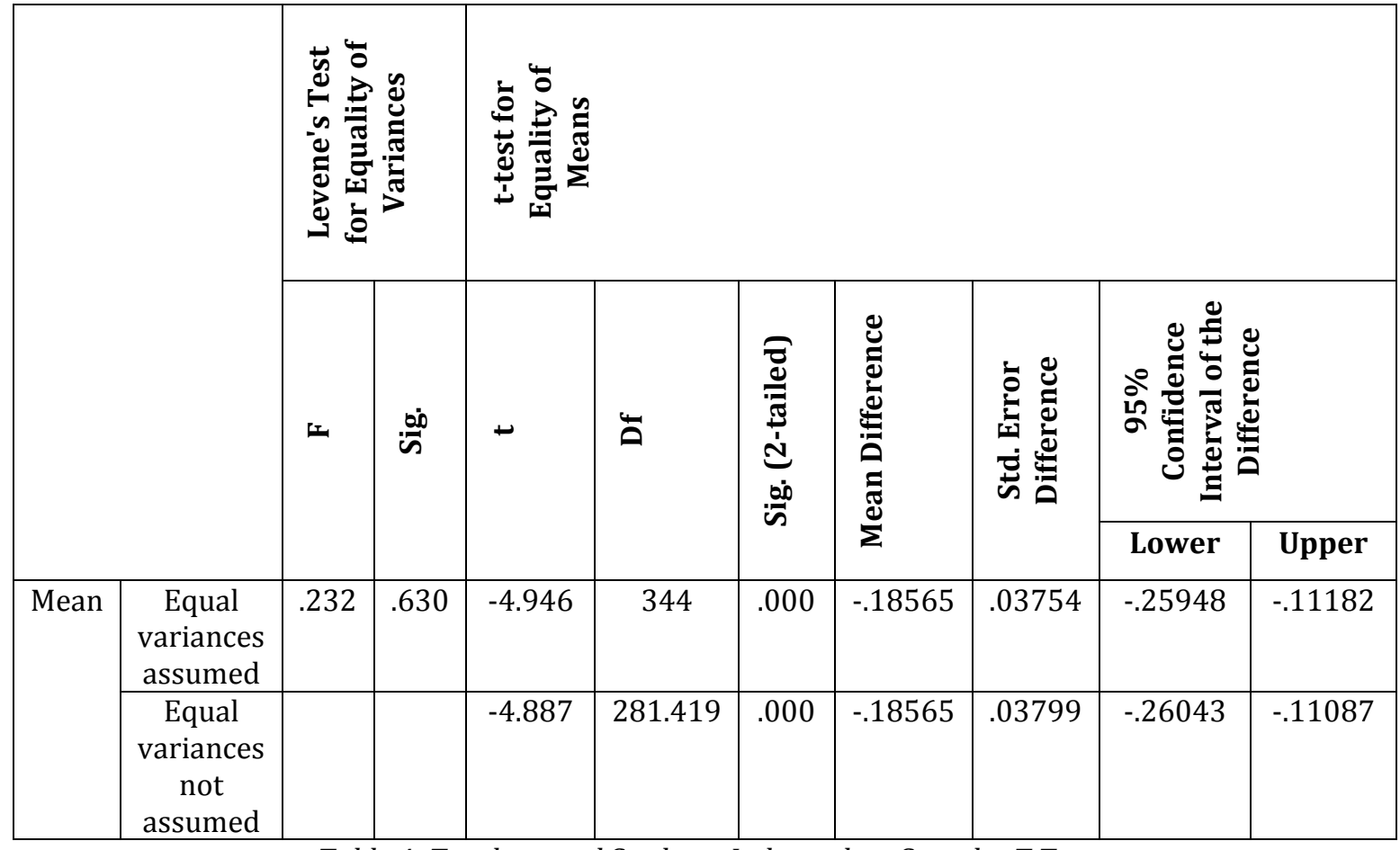

Table 4: Teachers and Students Independent Samples T Test

Source: Field Data (2021)

Table 4 indicates that the Levene's Test for equality of variance when $p$ value for equal variances assumed is .630, $t$ is -4.946 , degrees of freedom (df) is 344 and $p$ value is .000 .

The decision rule suggests that, if the $p$ value is less than the alpha, then the null hypothesis is rejected and if the $p$ value is greater than the alpha, we fail to reject the null hypothesis. In this test, the $p$ value (2-tailed) was .00 and therefore, the null hypothesis was rejected. The findings therefore, implied that there was a significant statistical difference between teachers' $(M=2.76, S D=.35)$ and students' $(M=2.95, S D=.33)$ perceived level of knowledge on fire disaster preparedness in secondary schools in Kilimanjaro region; $t(344)=-4.95, p=.00$.

The findings remarkably indicated that teachers had a lower mean than students thus implying that students perceived to be more knowledgeable on fire disaster preparedness than teachers. This might have been due to students being exposed to more opportunities that foster their understanding on fire disaster preparedness than teachers. For instance, students are taught about fire safety aspects related to fire disaster preparedness in school. Furthermore, they are mostly engaged in extra-curricular activities that impart them with knowledge on fire disaster preparedness in scout clubs and red-cross clubs while teachers remain reluctant. To support this argument, a study conducted by Amuli (2019) revealed that, while scout clubs are used to train students, teachers who are their immediate supervisors are surprisingly not involved in the training exercise.

\section{Conclusion}

Based on the findings, only a fair number of heads of schools, teachers and students were prepared enough to effectively and efficiently respond to fire disasters, should such menaces occur in secondary schools. This situation exposes these school community members to greater risk of incurring the consequences associated with fire disasters, if they occur at school.

\section{Recommendations}

This study recommends that regular trainings on fire safety management should be conducted in schools in order to impart more knowledge on fire disaster preparedness to students and staff. Subsequently, such effort is expected to enhance fire safety in secondary schools. Furthermore, this study recommends that Tanzania Institute of Education to integrate comprehensive topics on disaster management in the ordinary level secondary education syllabi. This might help in imparting more knowledge on fire disaster preparedness to students and staff, thus making them more prepared to respond to fire disasters in secondary schools. In addition, this study recommends that heads of schools embrace diversity in different ways that help to impart more knowledge on fire disaster preparedness to students and staff. For example, students' level of knowledge on how to use different fire-fighting equipment, how to administer first aid, and how to raise a fire alarm can be enhanced by being engaged in extra-curricular activities like fire clubs, red-cross clubs, and scout clubs at school. 


\section{References}

i. Akpi, A. (2019). Theories of Knowledge Production in Disaster Management [University of Port Harcourt]. https://doi.org/10.13140/RG.2.2.11117.23523

ii. Alharbi, M. M., Horaib, Y. F., Almutairi, O. M., Alsuaidan, B. H., Alghoraibi, M. S., Alhadeedi, F. H., \& Alrowithi, A. S. (2016). Exploring the extent of knowledge of CPR skills among school teachers in Riyadh, KSA. Journal of Taibah University Medical Sciences, 11(5), 497-501. https://doi.org/10.1016/j.jtumed.2016.07.007

iii. Amuli, A. J. (2019). Efficacy of Fire Disaster Management Policies in Managing Fire Outbreaks in Tanzania's Secondary Schools. European Journal of Education Studies, 6(5), 350-366.

iv. Amuli, A. J. (2020). Fire Disaster Management Practices in Tanzania's Secondary Schools: A Case of Selected Secondary Schools. University of Dar es Salaam.

v. Ayonga, N. I. (2016). An investigation of fire emergency preparedness in kenyan schools. A case study of public secondary schools in Nairobi. The University of Nairobi.

vi. Díaz-vicario, A., Sallán, J. G., \& Díaz-vicario, A. (2017). A comprehensive approach to managing school safety: Case studies in Catalonia, Spain. Educational Research, 1881(February), 1-18. https://doi.org/10.1080/00131881.2016.1272430

vii. Gaikwad, G. C. (2019). A study to assess the knowledge and attitude of secondary school teachers regarding first aid management of selected emergencies among school children, at selected secondary schools at Ghataprabha, in view to prepare information booklet. International Journal of Advance Research, Ideas and Innovations in Technology, 5(2), 1292-1299.

viii. Kanyasan, K., Nonaka, D., Chatouphonexay, A., \& Hernandez, P. M. (2018). Implementation of disaster risk reduction and management policies in a school setting in Lao PDR: A case study. Tropical Medicine and Health RESEARCH, 7, 1-12.

ix. Mfinanga, A. W. (2016). Status of Emergency and Disaster Preparedness in Boarding Secondary Schools in Singida Region. The University of Dodoma.

x. Mugamu, E. (2018). Exploring the Level of Preparedness to Fire Risk in Schools in South Africa: A Case of Four Schools in Kayamandi Township, Stellenbosch. Stellenbosch University.

xi. Nanda Khoirunisa. (2016). Disaster Knowledge of Student for Disaster Preparedness. The First International Conference on Child - Friendly Education, 219-222. http://hdl.handle.net/11617/7217

xii. NASP. (2013). Rethinking School Safety: Communities and Schools Working Together. NASP.

xiii. Nestory, E. (2017). Fire Disaster Preparedness in Secondary Schools: A Case Study of Ilala Municipal Council. The Muhimbili University of Health and Allied Sciences.

xiv. Ogbonna, C., \& Nwaogazie, I. (2015). Fire safety preparedness in workplaces in Port Harcourt, Nigeria. International Journal of Hygiene and Environmental Health, 2(8), $112-121$. https://doi.org/10.15739/irjpeh.028

xv. Ogochukwu, S., Oduduabasi, E., \& Anake, U. (2019). Analysis of Fire Disaster Preparedness Among Secondary School in Port Harcourt Metropolis, River State/Nigeria. Global Scientific Journals, 7(10), 474-525.

xvi. Pinar, A. (2017). What is Secondary School Students' Awareness on Disasters? A Case Study. Review of International Geographical Education Online, 7(3), 315-331.

xvii. Rogers, R. W. (1983). Protection Motivation and Self-Efficacy: A Revised Theory of Fear Appeals and Attitude Change. Journal of Experimental Social Psychology, 19, 469-479.

xviii. Tuladhar, G., Yatabe, R., Bhandary, N., \& Dahal, R. (2015). Assessment of disaster risk reduction knowledge of school teachers in Nepal. International Journal of Health System and Disaster Management, 3(1), 20. https://doi.org/10.4103/2347-9019.147142 